\title{
The Effects of CSR Activities on Business According to Employee Perception
}

\author{
ANĐELKA STOJANOVIĆ*, NATALIJA SOFRANOVA**, \\ SANELA ARSIĆ* (1), ISIDORA MILOŠEVIĆ* \& \\ IV A N M I H A J L O I Ć* \\ *University of Belgrade, Technical Faculty in Bor, Vojske Jugoslavije 12, 19210 Bor, \\ Serbia. Email: saarsic@tfbor.bg.ac.rs \\ **Institute of Sectoral Management, The Russian Presidential Academy of National \\ Economy and Public Administration (RANEPA), Vernadskogo prospect 82, \\ Moscow, Russian Federation
}

Corporate social responsibility (CSR) has become a vital element for building a longterm relationship with a company's stakeholders. Different dimensions of a company's social initiatives in terms of internal and external CSR activities influence the satisfaction of employees with the purpose of improving the CSR application. The aim of this research is to examine the level of employees' awareness of the implementation of CSR in Serbian and Russian companies. A comparative analysis between these two countries was carried out in order to perceive the differences in attitudes of employees, their job satisfaction, and consequently the implementation of CSR. The hypotheses of the developed model were tested by using the Multigroup Confirmatory Factor Analysis. The obtained results offered several implications for scholars and practitioners that should be considered when formulating and implementing CSR actions.

\section{Introduction}

In recent years, there has been a growing interest in corporate social responsibility (CSR) throughout the world (Carroll 2016; Manasakis 2018; Gürlek \& Tuna 2019; Zhang et al. 2019; González-Rodríguez et al. 2019; Brower and Dacin 2020; González-Rodríguez and Díaz-Fernández 2020). The concept of CSR is a consequence of more demanding consumer requests to reduce the negative impact of business operations on their environments (Nasrullah and Rahim 2013). In today's business, companies are expected to have CSR programmes and consistently 
implement a defined social responsibility policy. In other words, to be a socially responsible company means not only fulfilling the obligations prescribed by law, but also investing in human capital, environment, and relationships with all stakeholders (Carroll, 1991). In addition, socially responsible tasks have been an integral part of managerial practice in companies to improve the general opinion of their brand image, making it appear as an essential element of their corporate identity (González-Rodríguez et al., 2015).

CSR is a concept whose first definition came in the mid-twentieth century. One of the first and the most prominent definitions of CSR was given by Howard Bowen (who Carroll, 1991, refers to as the father of CSR), and it stated: 'CSR is the obligation of businessmen to pursue those policies, to make those decisions, or to follow those lines of action which are desirable in terms of the objectives and values of our society' (Bowen, 1953). Dahlsrud (2008) analysed 37 definitions used by researchers in their studies on CSR and noticed that most of the definitions are based on five dimensions: the environmental, social, economic, stakeholder, and voluntariness dimensions. On the other hand, Rahman (2011) gave eleven dimensional points on CSR definitions: obligation to society, improving quality of life, economic development, stakeholder's involvement, law abiding, ethical business practices, voluntariness, human rights, environmental protection, transparency, and accountability.

From the practical point of view, on CSR activities, the following authors made a considerable contribution. Hopkins (2006) defined CSR as a consideration of the internal and external stakeholders of the company in an ethical and socially responsible way. The goal of social responsibility is to simultaneously enable the creation of high standards of living for all stakeholders while preserving profitability (Hopkins, 2006).

Gürlek and Tuna (2019) indicated that organizational identification of employees through CSR activities had an effect on the working engagement, and consequently had a positive effects on business results.

From a post-transitional countries' perspective, involving employees in CSR practices might be even more important than in developed economies. Developed economies have incorporated CSR into their business cultures and employees already have their place in companies as a valuable and important resource. Posttransition countries, on the other hand, are still developing their own specific ways to implement CSR practices and are trying to achieve a positive influence on employees and the environment (Habisch et al., 2005).

However, the empirical studies that deal with the concept of CSR in post-transitional countries, such as Serbia and Russia, are very limited. The results of available studies in the considered countries do not fully cover the field of interest related to the CSR concept, and the attitudes of employees, in particular their satisfaction (Alon et al. 2010; Milenković et al. 2010; Krasnopolskaya 2013; Đukić Ivanović 2014; Panova 2016). This can be considered as a research gap in the literature.

Therefore, the aim of this research, which was carried out in Serbian and Russian companies, was to investigate the employees' attitudes and opinions on the implementation of the CSR concept and to make a comparative analysis of the obtained results. For this purpose, the relationships of CSR dimensions and the internal and 
external CSR activities of the companies, as well as their impact on employees' satisfaction, which is a key factor in the success of CSR implantation, were examined. Hence, the authors have proposed a model for identification of the relationship between CSR activities and their influence on employee satisfaction and further CSR implementation.

This model can help decision-makers in companies to get a perception of the awareness and attitudes of employees of the CSR concept. In addition, the results of this research can contribute to the state of the art in scientific literature by indicating similarities and differences between analysed countries.

\section{The Theoretical Framework and Development of Hypotheses}

\subsection{CSR Dimensions}

CSR is a business concept applied by companies, beyond the limits prescribed by law, to balance relationships with stakeholders and integrate their expectations into business activities while ensuring the sustainability of the business. It is important to know the expectations of stakeholders and to align the company's activities with their interests because, in that way, the implementation of CSR is beneficial for all. It is also an additional motive for the company to further invest in CSR activities. Stakeholder perception is a widely accepted way to research CSR (Arrive et al. 2019; Zhang et al. 2019; Dhanesh, 2020). Consumer perceptions of CSR mediate the relationship between human values and entrepreneurs' perceptions of CSR, and significant differences can be found in consumers' and entrepreneurs' perceptions of CSR with respect to the cultural environment (González-Rodríguez et al. 2015).

The consideration of CSR can be done through several key interrelated dimensions dealing with the most important problems of society and the environment (Gonzalez-Rodríguez et al. 2015; Arsić et al. 2017; Stojanovic et al. 2020). In this article, the extent to which the company adopts the five dimensions of CSR proposed by Dahlsrud (2008) has been analysed from the stakeholder perspective, i.e. the employees' perception.

The economic responsibility of companies derives from the legally regulated definition of the company, which states that the basic function of the company is to carry out business activities and to increase the value of the invested assets in the long run, thereby justifying the trust of shareholders (Kang and Moon, 2012). The only way that shareholders realize the return of invested funds is through profitability, which is the most important and basic goal of the business economy. Companies that focus their activities only on making profits lead to the creation of strong corporations; however, then the interests of society and the community remain neglected. Companies have become aware that their existence in the market depends on partially sacrificing their short-term profits for the positive effects in the future (Saeidi et al. 2015). Today, companies that have succeeded in adapting to this type of business are market leaders.

Environmental awareness appeared as a result of the pronounced ecological crisis during the 1970s. Although significant measures have been taken to reduce 
environmental imbalances over time, the need for building and raising the level of environmental awareness continues and has become increasingly important (Chirstmann 2004). Environmental awareness consists of performances, modes of behaviour, motives for action, desires and expectations that relate to a human's natural environment. In recent years, companies have become increasingly under pressure to comply with regulations on environmental protection and transparency. The starting point of the concept of the environmental dimension is that companies have the responsibility to protect the environment and improve it.

The social dimension refers to the existence of a relationship between the companies and the vicinity in which they operate (Nasrullah and Rahim 2013). First, companies should accept responsibility for the impact that they have on society and balance the external and internal consequences of their actions. The social dimension of CSR includes improving reputation, brand values, employee satisfaction, management, environmental conservation, and philanthropic activities. Social activities can be measured through the contribution to society, strategic partnerships, the impact on the local community, and the time spent in volunteering (Brockett and Rezaee 2012).

The economic, environmental and social dimension of CSR is known as the triple bottom line (Elkington 1997). In addition to the three basic dimensions, two more dimensions have appeared in recent years: stakeholders and voluntariness (Slack et al. 2013). In recent years, companies have been put under increasing pressure to act socially responsibly towards different stakeholders in business (Okpara and Wynn, 2012) and, based on this, the stakeholder dimension arises. The groups interested in the operations of one company include internal (employees, shareholders, managers, etc.) and external groups (customers, suppliers, competitors, state authorities, etc.) (Scandelius and Cohen 2016). The stakeholder dimension aims to balance stakeholder interests and to prevent the unethical behaviour of companies. The dimension of voluntariness relates to the arbitrary engagement of companies in the interest of employees with regard to contributing to their knowledge and experience of both the company in which they operate and the wider community in which they live (Ortas et al. 2015). Voluntary activities are numerous and there are more and more companies that encourage employees to become involved and help improve society and the environment. Based on the facts and the importance of CSR dimensions for the successful operation of the company, the following hypotheses were developed, and they are tested in this article:

H1: The CSR dimensions positively influence internal activities in Serbian and Russian companies.

H2: The CSR dimensions positively influence external activities in Serbian and Russian companies.

\subsection{Internal and External CSR Activities}

The activities of the companies that are socially responsible can be divided into internal and external activities (Farooq et al. 2014). The division made in this 
way according to Hameed et al. (2016) relates to perceived external CSR efforts aimed at meeting the expectations of external stakeholders, and internal CSR activities related to employees.

Within the company, socially responsible practices involve employees and relate to activities such as investing in human capital, education, overall improvement of the employees' skills, health and safety, and managing change (Mijatovic et al. 2015). Active monitoring of the employees who cannot work due to disability or injury at work is also part of the CSR (Rusmanto and Williams, 2015). Responsible employment practices include non-discriminatory practices that contribute to the employment of minority members, older workers, women, long-term unemployed, and persons with disabilities. These contribute to achieving the goals of the European Employment Strategy - reducing unemployment and combating social exclusion of individuals.

In addition to internal activities, the concept of CSR should also be directed towards the community that external CSR activities are focused on. The growing requirements of society towards the practices of companies that have a greater orientation towards their various stakeholders have become evident in all activity sectors. Hence, this continuous pressure from different stakeholders in firms and society as a whole has generated greater concern among managers about the essential aspects required for a company to grow and survive (González-Rodríguez et al. 2015; González-Rodríguez and Díaz-Fernández 2020). Hence, it is necessary that the socially responsible business extends beyond the company itself to the local community and to various stakeholders, business partners and suppliers, consumers, public administration, and local NGOs. This aspect of socially responsible business is more visible to the public and makes the company recognizable. The companies contribute to local communities through job security and payment of taxes, donations, sponsorships, social-oriented marketing campaigns, and corporate funds. Investing in the quality of life in the community in which the company operates, as well as taking care of the satisfaction of people working within the company, will not jeopardize the profit of the company but it will contribute to its general development and help those who really need it (Kim et al. 2018).

Establishing links between CSR activities and employees is often performed directly in research (Turker 2009; Lee et al. 2013; Appiah 2019). In contrast, in a study conducted by Hameed et al. (2016) it was assumed that such links are established indirectly through internally and externally oriented CSR activities. The results indicate the justification of this division given that it was found that there are different mechanisms of influence of internal and external CSR activities of employees and their identification with the company (Hur et al. 2019; Jia et al. 2019). Based on the literature analysed, the following hypotheses have been defined.

H3: The internal CSR activities of the companies positively influence the satisfaction of the employees in the concerned countries.

H4: The external CSR activities of the companies positively influence the satisfaction of the employees in the concerned countries. 


\subsection{Satisfaction of Employees}

Successful companies around the world look at their employees as the primary development resource and invest a lot of money in the implementation of CSR activities. Emphasis is put on actively managing employees' potentials.

The decisions of stakeholders are often made based on the reputation of the organization, whether the stakeholders are customers, business partners or employees. By creating a good CSR reputation, the company gets a tool with which it harmonizes the different expectations of stakeholders (Tkalac Verčič and Sinčić Ćorić 2018). A strong corporate culture and a reputation created by CSR are proven to be associated with employee satisfaction and commitment (Chun and Davies 2010; Young et al. 2018). Employees' satisfaction signals that adequate steps have been taken for the implementation of CSR. Research shows that employees who participate in the socially responsible activities of their company have a greater sense of subjective well-being, which contributes to a pleasant working environment and greater customer satisfaction (Hu et al. 2019). In their research, Tao et al. (2018) concluded that empowering employees to participate in CSR decision-making increased their sense of competence and connection, and improved their relationship with the company. The success of modern companies is no longer measured only by realizing a profit but also by considering the interests of various internal and external groups. Additionally, the previous studies revealed that internal CSR activities had a greater influence on employee engagement than external ones (Gupta and Sharma 2016; Chaudhary 2017). Chi and Chen (2020) even established and proved the relationship between employee satisfaction and financial condition of the company, which further indicated the importance of CSR implementation. In his paper, Appiah (2019) pointed out the positive link between job satisfaction and employee involvement in further CSR activities. Employee's attitudes about CSR activities are a significant factor for the level of implementation in the company, especially when implementing activities related to the employees themselves (Lee et al. 2013). Satisfied employees are the key to the success of a modern enterprise (Saeidi et al. 2015) and they greatly influence the implementation of the CSR concept, on the basis of which the following hypothesis is defined:

H5: Employee satisfaction has a positive impact on CSR implementation.

Based on the theoretical background, presented through the proposed hypotheses, a conceptual model was developed (see Figure 1).

\section{Methodology}

To test the proposed hypotheses of the research, presented in Figure 1, the Multigroup Confirmatory Factor Analysis (MGCFA) was applied (French and Finch 2006). The following sections describe in detail the data collection, the characteristics 


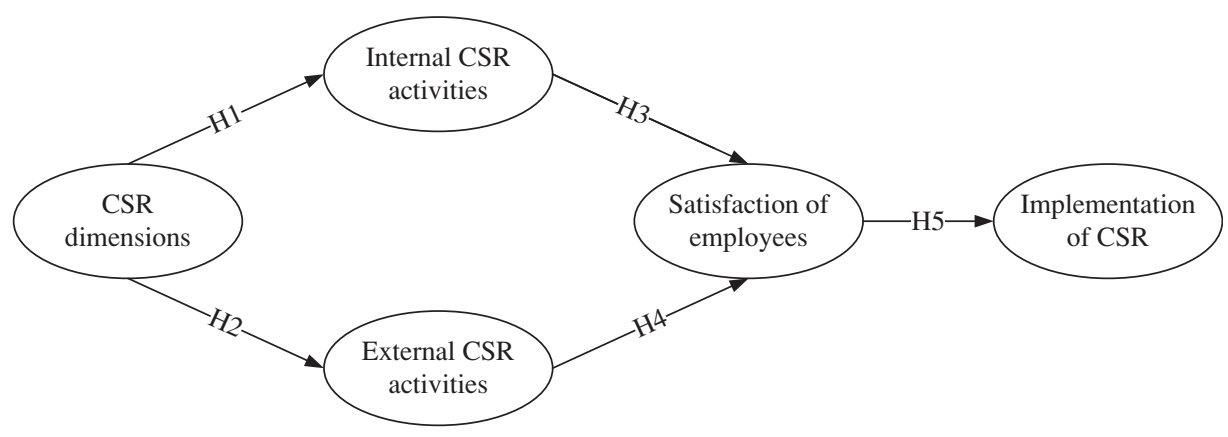

Figure 1. Conceptual model.

of the sample, and the measurement scales of the constructs involved in the defined research model.

\subsection{Sample and Data Collection}

To gather the sample, the questionnaire was distributed using a random sampling technique. In order to analyse the perceptions of employees' awareness of the implementation of CSR, a structured questionnaire divided into two different parts was designed. The questionnaire (see the Appendix), using a comprehensive literature review, was developed based on previously validated measurement scales, and for the requirements of this research the wording was slightly modified (Turker 2009; Fortier 2013). The survey included questions related to the constructs that were related to the perception of CSR dimensions, internal and external CSR activities, the satisfaction of employees, and implementation of CSR. In addition, the sociodemographic variables of the respondents were also included in the survey. The survey was translated into Serbian and Russian and distributed in Serbia and Russia. The respondents from the two countries were selected randomly, but with the intention to interview employees working in various companies and taking into consideration the uniformity of the samples. The reason for this was to ensure an adequate basis for comparison of the two countries, which have a similar historical-social background but different economic position currently. A survey among the employees was carried out by direct interviewing in order to ensure the questions were correctly understood and the answers were properly interpreted. In the Russian Federation, a CSR is characterized by a number of specificities adopted by Russian companies, where the development of CSR has had a form of active interaction between business and society. On the other hand, the concept of CSR was brought to Serbia by large multinational companies as an integral part of the business (Đukić Ivanović 2014). Many companies in Serbia still lack awareness and knowledge of the benefits of socially responsible business because they perceive this as activities that require investments and do not bring immediately visible profit (Milenković et al. 2010). 
A literature review has led to identifying the measurement scale for each construct of the research model that accounts for validation. Thus, to measure employees' awareness of the implementation of CSR, the questionnaire included 28 items. Participants answered to what extent they agree with the claims on a Likert scale ranging from 1 to 5 ('I don't identify myself with him at all' to 'I identify myself completely with him'). A total of 338 properly completed questionnaires of employees from Russia (47.87\%) and 368 of employees from Serbia $(52.12 \%)$ were collected. For analysis, the data were processed with SPSS 17.0 and AMOS. The socio-demographic profile of the participants of the two analysed countries is given in Table 1 .

\section{Results of the Research}

The results of the research are given in two segments. The first segment presents the results of the measurement model, using confirmatory factor analysis, with the purpose of confirming the reliability and validity of the measurement scale (Fornell and Larcker 1981). After the estimating measurement model, in the second segment, the testing of structural relationships using multi-group confirmatory factor analysis was conducted for Serbia and Russia.

\subsection{Measurement Model of CSR}

Testing the measurement invariance consists of a series of model comparisons that define increasingly stringent equality constraints (Byrne 2010; Hirschfeld and von Brachel 2014). To ensure internal consistency of a measurement, a Cronbach's alpha reliability coefficient (Cronbach 1951) was calculated for each construct. The individual measures included in the survey are depicted in Table 2. All the constructs have acceptable values where, within each group of questions (Nannally 1978), it is suggested that a value $\geq 0.7$ is considered a priority. The values of the load factors and a critical relation are also shown in Table 2, depicting that all the constructs have a convergent validity in both observed groups of approximately 0.5 (AVE $\geq 0.5$ ) (Hair et al. 1998).

Multi-group confirmatory factor analysis was done where the correlation matrix was tested for both observed sample groups, and where the maximum likelihood method was applied. In Table 3, the correlation between constructs for Serbian respondents is given below the diagonal, whereas for Russian respondents it is given above the diagonal.

A multi-group confirmatory factor analysis was performed across samples of Serbian and Russian companies. The chi-square value for the measuring model was $981.8(\mathrm{df}=626)$ with statistical significance $(p<0.05)$, while the relative chisquare value for the defined measuring model was 1.568 , which was below the required limit of 3 , indicating that this model has acceptable fit. Several different model indices of fit were evaluated, including the RMSEA, where excellent 
Table 1. Descriptive statistics of the sample.

\begin{tabular}{|c|c|c|c|c|c|}
\hline & & & Russia & & Serbia \\
\hline Variables & Category & $N$ & $\begin{array}{c}\text { Percentage } \\
\text { within Country } \\
(\%)\end{array}$ & $N$ & $\begin{array}{c}\text { Percentage } \\
\text { within Country } \\
(\%)\end{array}$ \\
\hline \multirow{6}{*}{ Age } & $18-25$ & 110 & 32.5 & 16 & 4.3 \\
\hline & $26-35$ & 166 & 49.1 & 132 & 35.9 \\
\hline & $36-45$ & 50 & 14.8 & 78 & 21.2 \\
\hline & $46-55$ & 12 & 3.6 & 130 & 35.3 \\
\hline & $55-65$ & 0 & 0 & 6 & 1.6 \\
\hline & Over 65 & 0 & 0 & 6 & 1.6 \\
\hline \multirow[t]{2}{*}{ Gender } & Male & 124 & 36.7 & 148 & 40.2 \\
\hline & Female & 214 & 63.3 & 220 & 59.8 \\
\hline \multirow[t]{6}{*}{$\begin{array}{l}\text { Level of } \\
\text { education }\end{array}$} & $\begin{array}{l}\text { High school diploma } \\
\text { and under diploma }\end{array}$ & 26 & 7.7 & 24 & 6.5 \\
\hline & $\begin{array}{l}\text { Diploma of Vocational } \\
\text { Education }\end{array}$ & 124 & 36.7 & 212 & 57.6 \\
\hline & $\mathrm{BSc}$ & 98 & 29 & 88 & 23.9 \\
\hline & $\mathrm{MSc}$ & 52 & 15.4 & 26 & 7.1 \\
\hline & $\mathrm{PhD}$ & 4 & 1.2 & 12 & 3.3 \\
\hline & Other & 34 & 10.1 & 6 & 1.6 \\
\hline \multirow{5}{*}{$\begin{array}{l}\text { Years of work } \\
\text { experience }\end{array}$} & Up to 5 & 228 & 67.5 & 132 & 35.9 \\
\hline & $6-10$ & 64 & 18.9 & 80 & 21.7 \\
\hline & $11-20$ & 40 & 11.8 & 78 & 21.2 \\
\hline & $21-30$ & 6 & 1.8 & 34 & 9.2 \\
\hline & Over 30 years & 0 & 0 & 44 & 12 \\
\hline \multirow[t]{6}{*}{ Firm age } & $0-5$ & 44 & 13 & 12 & 3.3 \\
\hline & $6-10$ & 68 & 20.1 & 22 & 6 \\
\hline & $11-15$ & 70 & 20.7 & 64 & 17.4 \\
\hline & $16-20$ & 48 & 14.2 & 86 & 23.4 \\
\hline & $21-50$ & 86 & 25.4 & 92 & 25 \\
\hline & $>50$ & 22 & 6.5 & 92 & 25 \\
\hline \multirow{7}{*}{$\begin{array}{l}\text { Current firm size } \\
\text { (number of } \\
\text { employees) }\end{array}$} & $4-10$ & 22 & 6.5 & 18 & 4.9 \\
\hline & $11-50$ & 100 & 29.6 & 54 & 14.7 \\
\hline & $51-100$ & 22 & 6.5 & 72 & 19.6 \\
\hline & $101-250$ & 18 & 5.3 & 70 & 19 \\
\hline & $251-500$ & 18 & 5.3 & 28 & 7.6 \\
\hline & $501-1000$ & 34 & 10.1 & 58 & 15.8 \\
\hline & $>1000$ & 124 & 36.7 & 68 & 18.5 \\
\hline
\end{tabular}

model fit was suggested by values less than or equal to 0.06 . The value of RMSEA in this case was 0.040 , which further suggested that the model fit was adequate. The CFI, TLI, NNFI, NFI and RFI was where excellent model fit was suggested by values greater than or equal to 0.95 (Table 4 ), while acceptable model fit was suggested by values between 0.90 and 0.95 (Tucker and Lewis 1973; Bollen 1986; Steiger 1990). The results depict that all the values have an acceptable model fit. 
Table 2. Measurement model of CSR in Serbia and Russia.

\begin{tabular}{|c|c|c|c|c|c|c|c|c|c|}
\hline \multirow[b]{2}{*}{ Constructs } & \multicolumn{5}{|c|}{ Serbian $(n=368)$} & \multicolumn{4}{|c|}{ Russia $(n=338)$} \\
\hline & Indicators & $\begin{array}{c}\begin{array}{c}\text { Standardized } \\
\text { loading }\end{array} \\
\end{array}$ & AVE & C.R & $a$ & $\begin{array}{l}\text { Standardized } \\
\text { loading }\end{array}$ & AVE & C.R & $a$ \\
\hline \multirow{5}{*}{ CSR dimensions } & D1 & 0.815 & & 9.492 & & 0.741 & & 6.071 & \\
\hline & D2 & 0.902 & & 10.046 & & 0.829 & & 6.321 & \\
\hline & D3 & 0.741 & 0.627 & 8.914 & 0.881 & 0.812 & 0.526 & 6.304 & 0.841 \\
\hline & D4 & 0.818 & & 10.382 & & 0.726 & & 6.691 & \\
\hline & D5 & 0.662 & & & & 0.454 & & & \\
\hline \multirow{7}{*}{$\begin{array}{c}\text { Internal CSR } \\
\text { activities }\end{array}$} & IA1 & 0.605 & & & & 0.621 & & & \\
\hline & IA2 & 0.774 & & 8.840 & & 0.739 & & 8.718 & \\
\hline & IA3 & 0.683 & & 7.380 & & 0.639 & & 8.337 & \\
\hline & IA4 & 0.712 & 0.477 & 7.074 & 0.872 & 0.741 & 0.472 & 7.880 & 0.864 \\
\hline & IA5 & 0.723 & & 6.997 & & 0.526 & & 5.851 & \\
\hline & IA6 & 0.681 & & 7.045 & & 0.733 & & 7.861 & \\
\hline & IA7 & 0.643 & & 7.391 & & 0.775 & & 8.344 & \\
\hline \multirow{4}{*}{$\begin{array}{l}\text { External CSR } \\
\text { activities }\end{array}$} & EA1 & 0.573 & & & & 0.562 & & & \\
\hline & EA2 & 0.778 & & 7.680 & & 0.680 & 0.422 & 6.423 & 0.801 \\
\hline & EA3 & 0.941 & 0.588 & 8.303 & 0.838 & 0.597 & & 5.933 & \\
\hline & EA4 & 0.729 & & 7.410 & & 0.745 & & 6.704 & \\
\hline \multirow{7}{*}{$\begin{array}{l}\text { Satisfaction of } \\
\text { employees }\end{array}$} & SE1 & 0.551 & & 6.071 & & 0.689 & & 8.941 & \\
\hline & SE2 & 0.615 & & 6.670 & & 0.539 & & 6.940 & \\
\hline & SE3 & 0.618 & & 6.601 & & 0.594 & 0.428 & 7.657 & \\
\hline & SE4 & 0.752 & 0.399 & 7.599 & 0.821 & 0.606 & & 7.792 & 0.846 \\
\hline & SE5 & 0.519 & & 5.641 & & 0.635 & & 8.195 & \\
\hline & SE6 & 0.710 & & 7.329 & & 0.734 & & 9.561 & \\
\hline & SE7 & 0.623 & & & & 0.756 & & & \\
\hline \multirow{5}{*}{$\begin{array}{l}\text { Implementation } \\
\text { of CSR }\end{array}$} & I1 & 0.660 & & & & 0.670 & & & \\
\hline & $\mathrm{I} 2$ & 0.724 & & 12.053 & & 0.767 & & 10.996 & \\
\hline & $\mathrm{I} 3$ & 0.689 & 0.495 & 7.706 & 0.847 & 0.830 & 0.498 & 8.881 & 0.834 \\
\hline & I4 & 0.708 & & 7.706 & & 0.703 & & 8.004 & \\
\hline & I5 & 0.736 & & 8.053 & & 0.522 & & 6.401 & \\
\hline
\end{tabular}


Table 3. Correlation matrix.

\begin{tabular}{|c|c|c|c|c|c|}
\hline Serbia & $\begin{array}{c}\text { CSR } \\
\text { dimensions }\end{array}$ & $\begin{array}{l}\text { Internal } \\
\text { CSR } \\
\text { activities }\end{array}$ & $\begin{array}{l}\text { External } \\
\text { CSR } \\
\text { activities }\end{array}$ & $\begin{array}{l}\text { Satisfaction } \\
\text { of employees }\end{array}$ & $\begin{array}{c}\text { Implementation } \\
\text { of CSR }\end{array}$ \\
\hline CSR dimensions & 1 & $0.730 * * *$ & $0.681 * * *$ & $0.681 * * *$ & $0.668 * * *$ \\
\hline $\begin{array}{c}\text { Internal CSR } \\
\text { activities }\end{array}$ & $0.606^{* * *}$ & 1 & $0.631 * * *$ & $0.730 * * *$ & $0.363 * * *$ \\
\hline $\begin{array}{l}\text { External CSR } \\
\text { activities }\end{array}$ & $0.638 * * *$ & $0.347 * * *$ & 1 & $0.593 * * *$ & $0.509 * * *$ \\
\hline $\begin{array}{c}\text { Satisfaction of } \\
\text { employees }\end{array}$ & $0.417 * * *$ & $0.712 * * *$ & $0249^{*}$ & 1 & $0.420 * * *$ \\
\hline $\begin{array}{l}\text { Implementation } \\
\text { of CSR }\end{array}$ & $0.427 * * *$ & $0.266^{*}$ & $0.465^{* * *}$ & 0.077 n.s. & 1 \\
\hline
\end{tabular}

${ }^{* * *} p<0.001 ;{ }^{* *} p>0.01 ;{ }^{*} p<0.05 ;$ n.s. $p>0.05$.

Table 4. Fit index for structural model.

\begin{tabular}{|c|c|c|c|c|c|}
\hline Model & & RMSEA & IFI & TLI & CFI \\
\hline Variant model & $\begin{array}{l}\text { Chi square }=970.919 \\
\mathrm{df}=645 \\
\chi=1.505\end{array}$ & 0.038 & 0.934 & 0.921 & 0.932 \\
\hline Invariant model & $\begin{array}{l}\text { Chi square }=1005.256 \\
\mathrm{df}=650 \\
\chi=1.546\end{array}$ & 0.039 & 0.928 & 0.914 & 0.926 \\
\hline
\end{tabular}

\subsection{Multi-group Analysis of Structural Models and Hypotheses Testing}

After confirming the group-invariance of the measurement model in this research, the estimation of separate structural models for each group was performed to see if there were any substantive differences in their structural relationships (Milošević et al. 2018). To obtain more compelling evidence of invariance and variance in the path coefficients across the two groups, the Structural Equation Model Multi-Group Analysis was performed. All goodness-of-fit and model comparison chi-square values were significant, and all the values were above the recommended values, as shown in Table 4.

To analyse the data and test the hypotheses, the sample was divided into two groups - Serbian and Russian respondents. Standardized factor loadings (Table 5) were greater than 0.60 for the group of Serbian respondents, with only the value for the construct 'Implementation of CSR' less than 0.60, whereas standardized factor loadings for Russian respondents were greater than 0.50 . Table 5 and Figure 2 show that all path coefficients for both observed groups were found with a positive and significant relationship, with the exception of the one considering 
Table 5. Multi-group confirmatory factor analysis.

\begin{tabular}{|c|c|c|c|c|}
\hline \multirow[b]{2}{*}{ Constructs } & \multicolumn{2}{|c|}{ Serbia $(n=368)$} & \multicolumn{2}{|c|}{ Russia $(n=338)$} \\
\hline & $\begin{array}{l}\text { Standardized } \\
\text { loading }\end{array}$ & $\mathrm{CR}$ & $\begin{array}{l}\text { Standardized } \\
\text { loading }\end{array}$ & $\mathrm{CR}$ \\
\hline CSR dimensions & $0.613-0.840$ & $10.879-12.385$ & $0.519-0.817$ & $\begin{array}{r}10.879- \\
12.385\end{array}$ \\
\hline Internal CSR activities & $0.701-0.835$ & $10.960-13.689$ & $0.575-0.775$ & $\begin{array}{r}10.960- \\
13.689\end{array}$ \\
\hline External CSR activities & $0.617-0.886$ & $9.796-10.528$ & $0.518-0.706$ & $9.796-10.528$ \\
\hline Satisfaction of employees & $0.634-0.746$ & $9.694-11.886$ & $0.572-0.704$ & $9.694-11.886$ \\
\hline Implementation of CSR & $0.524-0.902$ & $7.334-17.933$ & $0.456-0.874$ & $7.334-17933$ \\
\hline Path coefficients & $\begin{array}{r}\text { Standardized } \\
\text { parameters }\end{array}$ & T-value & $\begin{array}{l}\text { Causal rela- } \\
\text { tions }\end{array}$ & \\
\hline \multicolumn{5}{|l|}{ Serbia $(n=368)$} \\
\hline H1: CSR dimensions $\rightarrow$ Internal CSR activities & 0.598 (a) & 6.520 & Supported & \\
\hline $\mathrm{H} 2:$ CSR dimensions $\rightarrow$ External CSR activities & 0.669 (a) & 6.554 & Supported & \\
\hline H3: Internal CSR activities $\rightarrow$ Satisfaction of employees & 0.683 (a) & 7.372 & Supported & \\
\hline $\begin{array}{l}\text { H4: External CSR activities } \rightarrow \text { Satisfaction of employ- } \\
\text { ees }\end{array}$ & 0.065 (b) & 0.949 & l & \\
\hline $\begin{array}{l}\text { H5: Satisfaction of employees } \rightarrow \text { Implementation on } \\
\text { CSR }\end{array}$ & $0.803(\mathrm{a})$ & 3.742 & Supported & \\
\hline \multicolumn{5}{|l|}{ Russia $(\mathrm{n}=338)$} \\
\hline H1 CSR dimensions $\rightarrow$ Internal CSR activities & 0.760 (a) & 7.786 & Supported & \\
\hline H2 CSR dimensions $\rightarrow$ External CSR activities & $0.710(\mathrm{a})$ & 6.498 & Supported & \\
\hline H3 Internal CSR activities $\rightarrow$ Satisfaction of employees & 0.585 (a) & 6.467 & Supported & \\
\hline H4 External CSR activities $\rightarrow$ Satisfaction of employees & $0.268(a)$ & 3.214 & Supported & \\
\hline H5 Satisfaction of employees $\rightarrow$ Implementation on CSR & 0.860 (a) & 5.945 & Supported & \\
\hline
\end{tabular}




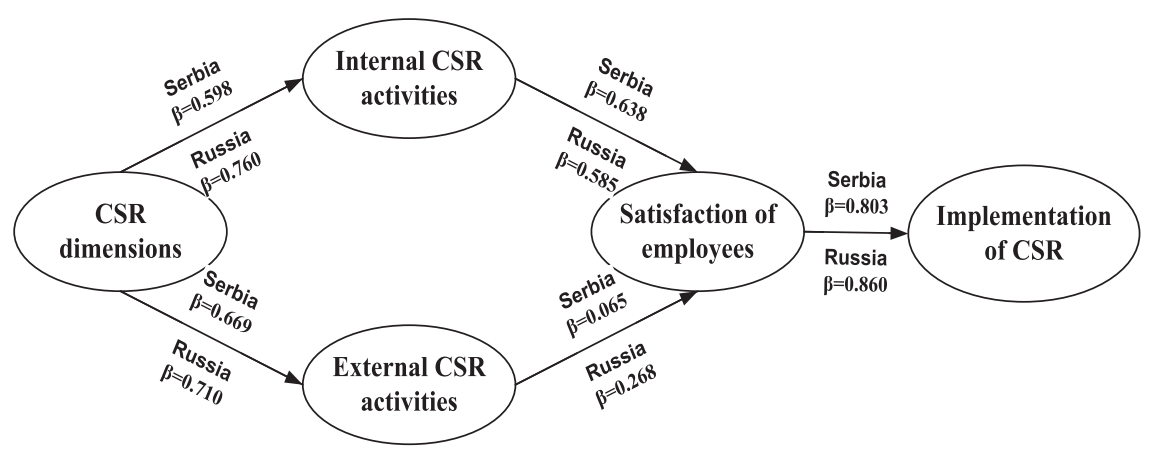

Figure 2. Structural model for both groups.

H4. In this case, the relationship had low statistical significance, but a positive path in both observed groups.

To test the model, the regression coefficients ( $\beta$ coefficient), and the coefficients of determination $R^{2}$ were used. The coefficient of determination revealed that the influence of latent constructs on the implementation of CSR can be determined with $19.58 \%$ of variance in the case of Serbia and $21.80 \%$ in the case of Russia.

The path analysis results (Figure 2) show that there is a very strong direct influence of CSR Dimensions to Internal CSR activities reflected in the beta coefficient of 0.598 $(p<0.001)$ for Serbia and $0.760(p<0.001)$ for Russia and this confirmed the first hypothesis (H1) for both observed groups. Also, H2 is confirmed because the CSR Dimensions have a strong direct influence with high statistical significance to External CSR activities $(\beta=0.669, p<0.001)$ for Serbia and $(\beta=0.710, p<0.001)$ for Russia. Hypothesis H3, which depicts the relation between the Internal CSR activities and the Satisfaction of employees, with a high positive direction and statistical significance for Serbia $(\beta=0.683, p<0.001)$ and for Russia $(\beta=0.585, p<0.001)$, is also accepted. The results indicate that External CSR activities have a positive effect but do not have a statistical significance on the Satisfaction of employees, with $\beta=0.065, p>0.5$ for Serbia. The result for Russia was different, with $\beta=0.268$ and statistical significance $p<0.001$. Hence, hypothesis H4 is supported in the Russia sample but in the Serbia sample it is insignificant. Finally, hypothesis H5 proves that Satisfaction of employees has a significant influence on the Implementation of CSR, which is confirmed by the beta coefficient of 0.803 in the case of Serbia and 0.860 in the case of Russia, with high statistical significance in both cases $(p<0.001)$.

\section{Discussion}

The Multi-group Confirmatory Factor Analysis methodology was employed to test the relationships in the defined research model. The multiple regression analysis was carried out to test the hypotheses that have been developed for this research based on five constructs: CSR dimensions, Internal CSR activities, External CSR activities, Satisfaction of employees, and Implementation of CSR. The obtained results of 
the research carried out in Russian and Serbian companies indicate that CSR Dimensions (economic, social, ecological, stakeholder, and voluntariness) have an influence on the satisfaction of employees and the implementation of CSR through the internal and external CSR activities. During research on CSR dimensions, Dahlsrud (2008) pointed to interviews as a way to define the concept of corporate social responsibility through stakeholder perceptions, and also cites research showing that respondents have had difficulty expressing the definition clearly. On the other hand, corporate identity is built on the identification of CSR and the company by stakeholders. Stakeholder attitudes and poor communication can significantly reduce the effectiveness of CSR (Dhanesh 2020). Therefore, it is important to examine whether respondents perceive CSR through the proposed dimensions and whether the level of this perception is related to the activities that the company implements. The first hypothesis (H1) observes the relation between perception of CSR dimensions and Internal CSR activities in Russian and Serbian companies, and it has been supported in both examined samples.

The CSR concept was brought to Serbia and Russia by large multinational companies in which CSR activities are an integral part of the business (Đukić Ivanović 2014; Stojanović et al. 2021). However, the research by Fifka and Pobizhan (2014) stressed that the political and socio-economic environment determines how companies practice internal CSR activities. The results of $\mathrm{H} 1$ indicate the existence of familiarity with CSR in the examined countries as well as the established relationship with efforts that companies undertake to improve employee status. Nowadays good reputation becomes an important driver for companies that want to present themselves as good 'social agents', which means that they do not pollute the environment, they help the community, nurture good relationships with external stakeholders, and take care of the welfare of the entire society. While behaving in that manner, companies can achieve a desirable reputation and sustainable competitive advantage.

Previous research conducted in Serbia and Russia pointed out that the companies that have chosen to operate in accordance with the CSR concept take care of numerous social groups and contribute to society through the mitigation of various social problems (Ivanović-Đukić 2011). In addition, companies in research countries strive to develop specific approaches in order to apply the comprehensive principles of international business based on transparency, environmental protections, external stakeholder relations and social solidarity (Morozova and Britvin 2013). In some cases, the companies operating in a socially responsible manner, have the main motive of a good image of the company (Milenković et al. 2010). However, their effective communication about business activities and values they want to promote raises awareness of CSR as a concept and its dimensions. In this research, hypothesis H2, which investigates the relation between CSR dimensions and External CSR activities in Russian and Serbian companies, has also been confirmed and contributes to previous understanding and acknowledgment of companies' CSR efforts and communication. The third hypothesis, related to the internal CSR activities of the companies and their influence on the satisfaction of the employees in the concerned countries, has also been confirmed. These results are in accordance with previous 
research, where it is proved that internal activities cause a high level of employee satisfaction, work engagement and organizational commitment (Hameed et al. 2016; Hur et al. 2019; Jia et al. 2019). The fourth hypothesis, which states 'The external CSR activities of the companies positively influence the satisfaction of the employees in the concerned countries' is supported in the case of Russia but is not supported in the case of Serbia. Much research has already proved that the direct influence of external CSR activities is non-existent or very low (Hameed et al. 2016; Hur et al. 2019; Jia et al. 2019). A similar conclusion is drawn by Farooq et al. (2014) who examined in their research how the CSR activities impact employees' organizational identification. In their research, a stronger impact is indicated for internal activities, but social activities were confirmed as an influential predictor for organizational identification and satisfaction. The findings of Gupta and Sharma (2016) reinforced the idea that internal and external CSR activities operated through different mechanisms on employees' satisfaction, where the effect of internal activities on employee engagement was greater than the influence of external activities.

Serbian employees consider that the external CSR activities do not matter so much for them because the direct benefits of external CSR activities are realized by the company, while the employees only realize indirect benefits. Similar results were obtained by Hur et al. (2019) and Jia et al. (2019) in their studies, which proved that the influence of external CSR activities on employee behaviour was more often indirectly manifested through elements such as organizational pride or perceived external prestige. Finally, hypothesis H5, which observes the relationship between employee satisfaction and CSR implementation, has been supported. This result is in line with previous research, which showed that company activities enabled numerous interventions to overcome the challenges and barriers that companies faced during CSR implementation (Garavan et al. 2010). Consequently, the research by Kunz (2020) pointed out that companies consciously used CSR to increase employee involvement, as employees who operate within a good working environment can stimulate productivity and contribute to the implementation of CSR activities to a greater extent (Stancu et al. 2011).

The comprehensive results of this research are in line with those of Chen et al. (2019), who pointed out that companies should recognize the importance of CSR activities, which can affect business operations. Successful companies have been developing specific strategies that rely on the different dimensions of CSR, and which are implemented through internal and external CSR activities. In this way, companies establish and strengthen ethical business conduct and ensure all stakeholders (internal and external), especially employees, behave honestly. In addition, they ensure that their corporate cultures are being fostered and aligned with their CSR activities.

\subsection{Theoretical and Practical Implications}

By revealing the importance of CSR activities on a critical group of stakeholders namely employees - this study contributes to the literature by analysing the data 
from Serbia and Russia, post-transitional economies that have not been examined in-depth in the recent literature compared with developed economies. In this way, the literature gap, which is identified as a research issue of this article, can be overcome. Considering that employee engagement and commitment affect organizational outcomes, understanding the importance of employee satisfaction should be a vital precondition for CSR implementation in companies. The obtained results can be very useful to managers of the companies that apply CSR to resolve practical dilemmas by placing emphasis on employee satisfaction, since higher job satisfaction may lead to greater employee commitment to organizational goals and values.

\subsection{Limitations and Future Research}

This study has some limitations that should be addressed in future research. First, the results of this study are focused only within the context of Serbian and Russian companies, where both countries are post-transitional. Different social and cultural surroundings may cause variations in attitudes toward CSR, therefore generalization of the results for other countries cannot be achieved. Future research on CSR can be broadened with investigations in other post-transitional countries as well as in the developed economies, which may enable results to be compared. Second, this study did not use some demographic data, such as firm age, firm size, respondent gender and level of education, in the analysis of the influence on observed constructs in the defined research model. Thus, future studies should consider these effects.

\section{Conclusion}

Considering that having a socially responsible business is becoming an increasingly important element in achieving competitive advantage in the market and in the efficient operation of modern companies, the question arises as to what extent Serbian and Russian companies have accepted and implemented the CSR concept. This study examined the employees' attitudes and opinions on the implementation of the internal and external CSR activities, which can contribute to CSR implementation in the firm's value creation. The survey was carried out in Serbian and Russian companies and comparative analysis of the obtained results was performed.

This study may inspire scholars to direct additional efforts to research specific segments of CSR implementation in different social-economic systems and other, different, cultures (González-Rodríguez et al. 2019). Furthermore, this study is aimed not only at scholars, but also practitioners, managers, owners, and other stakeholders who foster CSR and want to create valuable intangible capital and sustainable business. The main contribution of this article indicates that company managers should encourage positive work attitudes in employees by creating a trustworthy atmosphere based on the implementation of CSR strategies. Transparency and involvement of all employees are at the core of CSR and they contribute to its 
successful implementation. Therefore, companies should constantly implement activities that positively affect employee satisfaction and their job performance.

\section{Acknowledgements}

The authors would like to thank the editor and the anonymous reviewers for their very constructive and useful comments. The research presented in this article was carried out with the support of the Ministry of Education, Science and Technological Development of the Republic of Serbia, within the funding of the scientific research work at the University of Belgrade, Technical Faculty in Bor, according to the contract with registration number 451-03-9/2021-14/200131. The authors are also grateful to English language teacher Sandra Vasković for the English language edition of the article.

\section{References}

Alon I, Lattemann C, Fetscherin M, Li S and Schneider AM (2010) Usage of public corporate communications of social responsibility in Brazil, Russia, India and China (BRIC). International Journal of Emergency Management 5(1), 6-22.

Appiah J (2019) Community-based corporate social responsibility activities and employee job satisfaction in the U.S. hotel industry: an explanatory study. Journal of Hospitality and Tourism Management 38, 140-148.

Arrive T, Feng M, Yan Y and Chege S (2019) The involvement of telecommunication industry in the road to corporate sustainability and corporate social responsibility commitment. Corporate Social Responsibility and Environmental Management 26(1), 152-158.

Arsić S, Stojanović A and Mihajlović I (2017) The most important dimensions of Corporate Social Responsibility. Proceedings of the 13th International May Conference on Strategic Management - IMKSM 2017, pp. 436-454.

Bollen KA (1986) Sample size and Bentler and Bonett's nonnormed fit index. Psychometrika 51, 375-377.

Bowen H (1953) Social Responsibilities of the Businessman. New York: Harper.

Brockett AM and Rezaee Z (2012) Corporate Sustainability: Integrating Performance and Reporting. Hoboken, NJ: John Wiley \& Sons.

Brower J and Dacin P (2020) An institutional theory approach to the evolution of the corporate social performance - corporate financial performance relationship. Journal of Management Studies 57(4), 805-836.

Byrne BM (2010) Structural Equation Modeling with AMOS: Basic Concepts, Applications, and Programming. New York: Routledge.

Carroll AB (1991) The pyramid of corporate social responsibility: toward the moral management of organizational stakeholders. Business Horizons 34, 39-48.

Carroll A (2016) Carroll's pyramid of CSR: taking another look. Carroll International Journal of Corporate Social Responsibility 1(3), 1-8.

Chaudhary R (2017) Corporate social responsibility and employee engagement: can CSR help in redressing the engagement gap? Social Responsibility Journal 13(2), 323-338. 
Chen ZF, Hong C and Occa A (2019) How different CSR dimensions impact organization-employee relationships. Corporate Communications: An International Journal 24(1), 63-78.

Chi W and Chen Y (2020) Employee satisfaction and the cost of corporate borrowing. Finance Research Letters. doi: 10.1016/j.frl.2020.101666.

Chirstmann P (2004) Multinational corporations and the natural environment: determinants of corporate environmental policy standardization. Academy of Management Journal 47(5), 747-760.

Chun R and Davies G (2010) The effect of merger on employee views of corporate reputation: time and space dependent theory. Industrial Marketing Management 39(5), 721-727.

Cronbach LJ (1951) Coefficient alpha and the internal structure of test. Psychometrical 16, 297-334.

Dahlsrud A (2008) How CSR is defined: an analysis of 37 definitions. Corporate Social Responsibility and Environmental Management 15, 1-13.

Dhanesh G (2020) Who cares about organizational purpose and corporate social responsibility, and how can organizations adapt? A hypermodern perspective. Business Horizons 63, 585-594.

Đukić Ivanović M (2014) Leaders of social responsibility, market leaders. Belgrade 24-28.

Elkington J (1997) Cannibals with Forks: the Triple Bottom Line of 21st Century Business, 2nd edn. Oxford: Capstone Publishing.

Farooq M, Farooq O and Jasimuddin S (2014) Employees' response to corporate social responsibility: exploring the role of employees' collectivist orientation. European Management Journal 32, 916-927.

Fifka M and Pobizhan M (2014) An institutional approach to CSR in Russia. Journal of Cleaner Production 192-201.

Fornell C and Larcker DF (1981) Evaluating structural equation models with unobservable variables and measurement error. Journal of Marketing Research 18(1), $39-50$.

Fortier A (2013) The Effects of CSR on Employees' Job Satisfaction: An Empirical Study with Cross-Cultural Dimensions. Australia: Curtin University.

French B and Finch W (2006) Confirmatory factor analytic procedures for the determination of measurement invariance. Structural Equation Modelling 13, 378-402.

Garavan T, Heraty N, Rock A and Dalton E (2010) Conceptualizing the behavioral barriers to CSR and CS in organizations: a typology of HRD interventions. Advances in Developing Human Resources 12(5), 587-613.

González-Rodríguez R and Díaz-Fernández MC (2020) Customers' corporate social responsibility awareness and perception as antecedents of hotel image and repeat behaviour intention in green hotels. Corporate Social Responsibility and Environmental Management 27(3), 1294-1306.

González-Rodríguez MR, Díaz-Fernández MC and Simonetti B (2019) The perception of socially and environmentally responsible practices based on values and cultural environment from a customer perspective. Journal of Cleaner Production 216, 88-98.

Gonzalez-Rodríguez R, Diaz-Fernandez C and Simonetti B (2015) The social, economic and environmental dimensions of CSR: the role played by consumers and potential entrepreneurs. International Business Review 24, 836-848.

Gupta N and Sharma V (2016) The relationship between corporate social responsibility and employee engagement and its linkage to organizational performance: a conceptual model. The IUP Journal of Organizational Behavior 15(3), 59-75. 
Gürlek M and Tuna M (2019) Corporate social responsibility and work engagement: Evidence from the hotel industry. Tourism Management Perspectives 31, 195-208.

Habisch A, Wegner M, Schmidpeter R and Jonker J (2005) Corporate Social Responsibility across Europe. Berlin, Heidelberg: Springer.

Hair JF, Anderson RE, Tatham RL and Black WC (1998) Multivariate Data Analysis, 5th edn. New Jersey: Prentice Hall.

Hameed I, Riaz Z, Arain GA and Farooq O (2016) How do internal and external CSR affect employees' organizational identification? A perspective from the group engagement model. Frontiers in Psychology 7, 788.

Hirschfeld G and von Brachel R (2014) Multiple-group confirmatory factor analysis in R-A tutorial in measurement invariance with continuous and ordinal indicators. Practical Assessment, Research \& Evaluation 19(7), 1-14.

Hopkins M (2006) What is corporate social responsibility all about? Journal of Public Affairs 6(3-4), 298-306. https://doi.org/10.1002/pa.238

Hu B, Liu J and Qu H (2019) The employee-focused outcomes of CSR participation: The mediating role of psychological needs satisfaction. Journal of Hospitality and Tourism Management 41, 129-137.

Hur W-M, Moon T-W and Choi W-H (2019) When are internal and external corporate social responsibility initiatives amplified? Employee engagement in corporate social responsibility initiatives on prosocial and proactive behaviors. Corporate Social Responsibility and Environmental Management 26, 849-858.

Ivanović-Đukić I (2011) The promotion of corporate social responsibility in Serbia. Sociologija 1, 21-42.

Jia Y, Yan J, Liu T and Huang J (2019) How does internal and external CSR affect employees' work engagement? Exploring multiple mediation mechanisms and boundary conditions. International Journal of Environmental Research and Public Health 16(14), 2476.

Kang N and Moon J (2012) Institutional complementarity between corporate governance and CSR: a comparative institutional analysis of three capitalisms. SocioEconomic Review 10, 85-108.

Kim C, Kim J, Marshall R and Afzali H (2018) Stakeholder influence, institutional duality, and CSR involvement of MNC subsidiaries. Journal of Business Research 91, 40-47.

Krasnopolskaya II (2013) Communication of CSR and civil society: a theoretical justification. Civil Society in Russia and Abroad 2, 2-7.

Kunz J (2020) Corporate social responsibility and employees motivation - broadening the perspective. Schmalenbach Business Review 72, 159-191.

Lee EM, Park SY and Lee HJ (2013) Employee perception of CSR activities: its antecedents and consequences. Journal of Business Research 66(10), 1716-1724.

Manasakis C (2018) Business ethics and corporate social responsibility. Managerial and Decision Economics 39(4), 1-12.

Mijatovic I, Miladinovic S and Stokic D (2015) Corporate Social Responsibility in Serbia: between corporate philanthropy and standards. Corporate Social Responsibility in Europe. CSR, Sustainability, Ethics \& Governance 333-350.

Milenković B, Ć osović M and Stanković S (2010) CSR - the imperative of modern management. International Scientific Conference, MANAGEMENT 2010, Krusevac, Serbia, 220-225.

Milošević I, Trajković A, Rajić T, Nikolić Đ and Arsić S (2018) The effects of quality certification in establishing and developing customer - supplier relationships. Serbian Journal of Management 13(1), 115-131. 
Morozova IA and Britvin IA (2013) Basic forms of Corporate Social Responsibility in Russia. World Applied Sciences Journal 25(3), 441-445.

Nannally JC (1978) Psychometric Theory, 2nd edn. New York: McGraw-Hill.

Nasrullah NM and Rahim MM (2013) CSR in private enterprises in developing countries: evidences from the ready-made garments industry in Bangladesh. CSR, Sustainability, Ethics \& Governance. Switzerland: Springer.

Okpara JO and Wynn PM (2012) Stakeholders' perceptions about CSR: implications for poverty alleviation. Thunderbird International Business Review 54(1), 91-103.

Ortas E, Alvarez I, Jaussaud J and Garayar A (2015) The impact of institutional and social context on corporate environmental, social and governance performance of companies committed to voluntary CSR initiatives. Journal of Cleaner Production 108, 673-684.

Panova AJ (2016) CSR in the financial sphere. International Scientific and Research Journal 3(45), 60-63.

Rusmanto T and Williams C (2015) Compliance evaluation on CSR activities disclosure in Indonesian publicly listed companies. Global Conference on Business \& Social Science 172, 150-156.

Saeidi SP, Sofian S, Saeidi P, Saeidi SP and Saeidi SA (2015) How does CSR contribute to firm financial performance? The mediating role of competitive advantage, reputation, and customer satisfaction. Journal of Business Research $\mathbf{6 8}$, 341-350.

Scandelius C and Cohen G (2016) Achieving collaboration with diverse stakeholders the role of strategic ambiguity in CSR communication. Journal of Business Research, 69(9), 3487-3499.

Rahman S (2011) Evaluation of definitions: ten dimensions of CSR. World Review of Business Research 1(1), 166-176.

Slack N, Bardon-Jones A and Johnston R (2013) Operations Management, 7th edn. UK: Pearson.

Stancu A, Grigore GF and Rosca MI (2011) The impact of corporate social responsibility on employees. International Conference on Information and Finance IPEDR 21, 11-16.

Steiger JH (1990) Structural model evaluation and modification: an interval estimation approach. Multivariate Behavioral Research 25, 173-180.

Stojanović A, Mihajlović I, Safronova N, Kunev S and Schulte P (2021) The multicriteria analysis of corporate social responsibility: a comparative study of Russia, Bulgaria and Serbia. Journal of Management \& Organization, in press.

Stojanovic A, Milosevic I, Arsic S, Urosevic S and Mihaljovic I (2020) Corporate social responsibility as a determinant of employee loyalty and business performance. Journal of Competitiveness 12(2), 149-166.

Tao W, Song B, Ferguson MA and Kochhar S (2018) Employees' prosocial behavioral intentions through empowerment in CSR decision-making. Public Relations Review 44(5), 667-680.

Tkalac Verčič A and Sinčić Ćorić D (2018) The relationship between reputation, employer branding and corporate social responsibility. Public Relations Review 44, 444-452.

Tucker LR and Lewis C (1973) A reliability coefficient for maximum likelihood factor analysis. Psychometrika 38(1), 1-10.

Turker D (2009) How CSR influences organizational commitment. Journal of Business Ethics 89, 89-204. 
Young HR, Glerum DR, Wang W and Joseph DL (2018) Who are the most engaged at work? A meta-analysis of personality and employee engagement. Journal of Organisational Behavior 39(10), 1330-1346.

Zhang Q, Oo B and Lim B (2019) Drivers, motivations, and barriers to the implementation of corporate social responsibility practices by construction enterprises: a review. Journal of Cleaner Production 210, 563-584.

\section{About the Authors}

Anđelka Stojanović, MSc, is a Teaching Assistant at the Engineering Management Department, University of Belgrade, Technical Faculty in Bor. She teaches the following courses: Decision Making Theory, Reliability Theory, Logistics, Theoretical Fundamentals of the Master Work Preparation. The areas of her research interest and competence are: corporate social responsibility, and sustainability of business organizations, multi-criteria decision-making methods, statistical analysis.

Natalya Borisovna Safronova, PhD, is a Professor at the Institute of Sectoral Management, The Russian Presidential Academy of National Economy and Public Administration (RANEPA). Natalya's areas of scientific knowledge are: economics, economics of economic management, economics and organization of the enterprise, business management.

Sanela Arsić, PhD, is an Assistant Professor at the Technical Faculty in Bor, University of Belgrade. Her main research interests include multi-criteria decision-making methods, quality management, e-commerce, corporate social responsibility, and statistical data analysis. She is the author and co-author of a number of papers in international and national journals and conferences and has participated in several international research projects.

Isidora Milošević, $\mathrm{PhD}$, is an Associate Professor at the Technical Faculty in Bor, University of Belgrade. Her main research interests include strategic management, new technology and innovation, structural equation modelling, corporate social responsibility and marketing in small and medium-sized enterprises. She has co-authored a number of research papers that have been published in international scientific journals and has led several international research projects.

Ivan Mihajlović, $\mathrm{PhD}$, is a full professor at the University of Belgrade, Technical Faculty in Bor, Engineering Management Department. Currently, his main focus is on exploring and solving problems related to operational management with the application of methods of linear and nonlinear statistical analysis, kinetic analysis of technological processes and ecological management. He is the author or co-author of four books, five chapters in monographs, and over 120 papers published in international and national scientific journals. 


\section{Appendix}

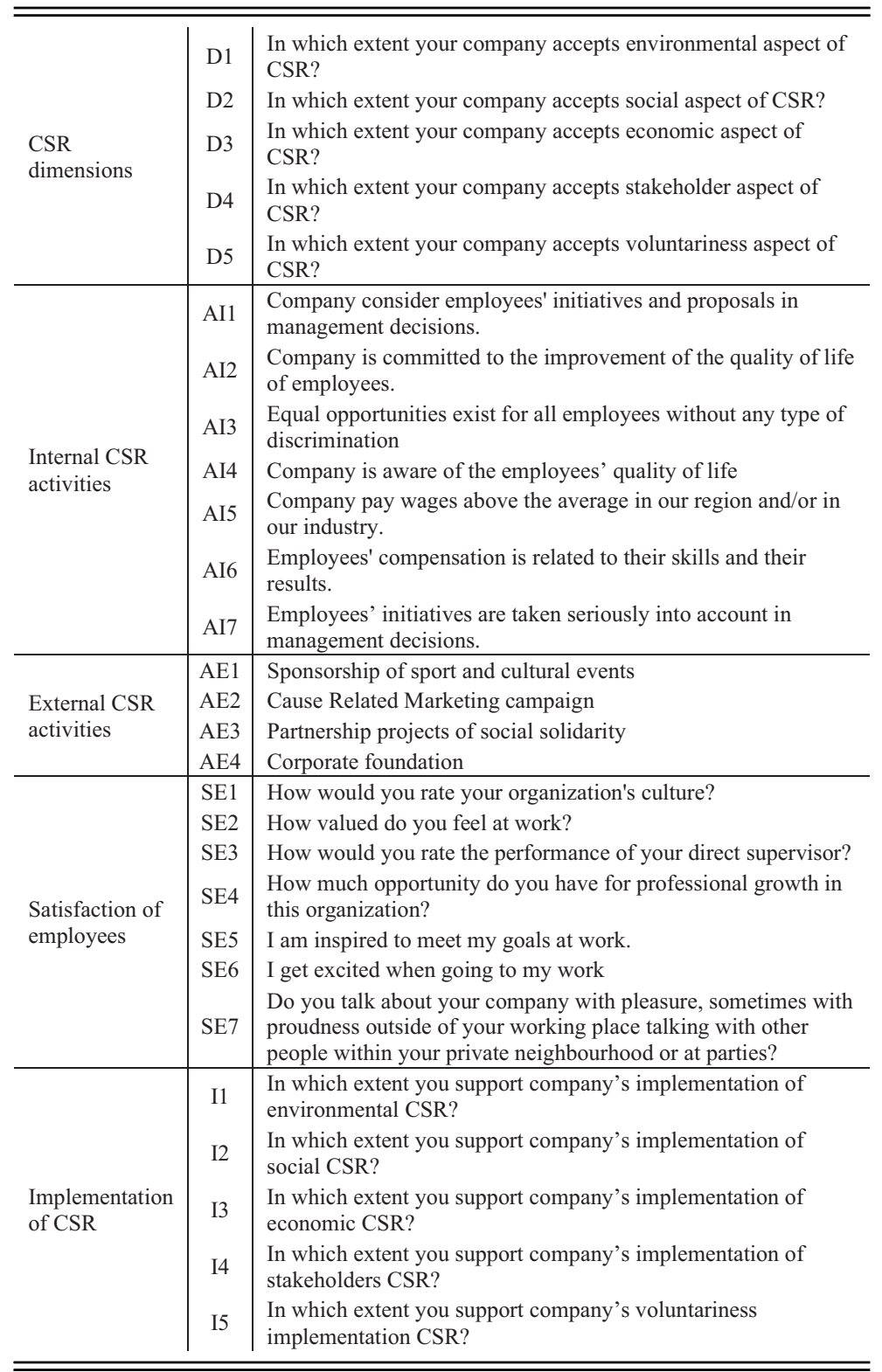

